\begin{tabular}{|l|l|l|l|l|l|}
\hline J. Tek. Ling & Vol. 12 & No. 3 & Hal. 291 - 298 & Jakarta, September 2011 & ISSN 1441-318X \\
\hline
\end{tabular}

\title{
ISOLASI DAN IDENTIFIKASI BAKTERI PENDEGRADASI HIDROKARBON YANG BERASAL DARI TANAH TERCEMAR MINYAK BUMI
}

\author{
Nida Sopiah, Avi N. Oktaviani, Susi Sulistia, Fuji Suciati, Dwindrata B. Aviantara \\ Peneliti di Balai Teknologi Lingkungan \\ Badan Pengkajian Penerapan Teknologi \\ nidasofiah@yahoo.com
}

\begin{abstract}
Abstark
Bioremediasi tanah tercemar minyak bumi telah diatur dalam Keputusan Menteri Negara Lingkungan Hidup nomor 128 Tahun 2003. Salah satu faktor yang menentukan keberhasilan penerapan bioremediasi adalah ketersediaan mikroorganisme yang mampu mendegradasi cemaran minyak bumi. Tujuan dari penelitian ini adalah mengisolasi dan mengidentifikasi konsorsium bakteri hidrokarbonklastik dari sampel tanah tercemar minyak bumi yang diperoleh dari Riau dan Bojonegoro. Dari hasil seleksi dan optimasi bakteri pada berbagai sampel tanah diperoleh empat isolate/konsorsium bakteri yang mampu mendegradasi minyak bumi, dengan kode konsorsium Ristek122-2.3; Ristek122-5; Ristek122-BN5; 122-Mix. Berdasarkan identifikasi dan uji biokimia, konsorsium bakteri terdiri dari bakteri hidrokarbonoklastik yang mampu menghasilkan biosurfaktan. Produksi biosurfaktan mampu menurunkan tegangan permukaan sehingga bakteri hidrokarbonoklastik mampu bekerja secara optimal.
\end{abstract}

Kata kunci : Bioremediasi,, minyak bumi, bakteri hidrokarbonoklastik, biosurfaktan

\begin{abstract}
Bioremediation of soils contaminated with crude oils is promulgated by regulation of Ministry of Environment number 128 year 2003. One of factors governing the success of applying bioremediation is availability of microorganisms capable of degrading the waste. Aims of this study were isolating and identifying microbial consortia of hidrocarbonoclastic from a serial of selection and isolation steps of crude oil-contaminated soil samples obtained from Riau and Bojonegoro. Bacterial selection and optimation steps resulted in four consortia identified as Ristek 122-2.3; Ristek 122-5; Ristek 122-BN5; Ristek 122Mix all having ability to degrade crude oils. Based on identification and biochemical test the consortia constitute of carbonoclastic bacteria and biosurfactant producing bacteria. The production of biosurfactant has reduced surface tension as such hidrocarbonoclatic bacteria capable of working optimally.
\end{abstract}

Key words : Bioremediation, crude oils, hidrocarbonoclatic bacteria,biosurfactant 


\section{PENDAHULUAN}

\subsection{Latar Belakang}

Bioremediasi tanah tercemar minyak bumi telah diatur dalam Keputusan Menteri Negara Lingkungan Hidup nomor 128 Tahun 2003 tentang tatacara dan persyaratan teknis pengolahan limbah minyak bumi dan tanah terkontaminasi oleh minyak bumi secara biologi. Bioremediasi merupakan suatu teknologi yang ramah lingkungan, yang mana bakteri memegang peranan yang sangat penting dalam proses degradasi limbah biologi ini. Tahapan proses bioremediasi tanah terkontaminasi minyak bumi mengalami dua fase. Fase pertama bakteri mampu dengan cepat mendegradasi limbah sebagai substrat sedangkan pada fase kedua dimana limbah tersebut diubah menjadi senyawa transisi berupa senyawa intermediate yang sulit didegradasi yang menjadikan kinerja bakteri tersebut mengalami penurunan. Dengan menurunnya kinerja bakteri ini dapat menyebabkan bertambah panjangnya masa bioremediasi

Hal ini menjadi tantangan, langkah apa yang harus dilakukan agar kinerja bakteri tetap terjaga. Salah satu upaya yang dilakukan adalah mengisolasi bakteri-bakteri hidrokarbonoklastik yang terlibat pada proses awal remediasi dan tahap intermediate pada proses remediasi tanah tercemar minyak bumi.

Selain itu diperlukan juga bakteri yang mampu menghasilkan biosurfaktan sehingga bakteri hidrokarbonoklastik tersebut mampu bekerja secara optimal. Dengan didapatkannya konsorsium bakteri tersebut diharapkan bioremediasi tanah terkontaminasi minyak bumi akan lebih cepat terpulihkan, sehingga dengan semakin pendeknya waktu bioremediasi maka jumlah tanah yang akan diremediasi akan lebih banyak.

\subsection{Tujuan}

Tujuan dari Kegiatan ini adalah mengisolasi dan mengidentifikasi konsorsium bakteri hidrokarbonoklastik dan bakteri biosurfaktan yang diperoleh dari tahapan seleksi dan isolasi dari beberapa sampel tanah tercemar minyak bumi yang berasal dari Riau dan Bojonegoro.

\section{METODE PENELITIAN}

\subsection{Sampling bakteri}

Sampling bakteri dilakukan dengan mengambil sejumlah sampel tanah tercemar minyak bumi yang telah mengalami proses remediasi.

Kegiatan penelitian ini dilakukan di beberapa lokasi :

a. Sampling bakteri pendegradasi hidrokarbon dilakukan di tiga lokasi, yaitu di Balai Teknologi Lingkungan BPPT Serpong, Badan Operasi Bersama PT. Bumi Siak Pusako, Pertamina Hulu, Zamrud, Riau dan tanah disekitar tempat penambangan rakyat Bojonegoro.

b. Seleksi dan Isolasi Bakteri Pendegradasi Hidrokarbon dilakukan di Balai Teknologi Lingkungan Badan Pengkajian dan Penerapan Teknologi (BTL - BPPT), berlokasi di Kawasan Puspiptek Serpong, Tangerang Selatan Banten.

c. Uji Biokimia Isolat/ Konsorsium bakteri pendegradasi hidrokarbon hasil seleksi di Laboratorium Bakteriologi, Fakultas Kedokteran Hewan, Institut Pertanian Bogor.

\subsection{Seleksi dan Isolasi bakteri pende- gradasi cemaran hidrokarbon}

Seleksi ini dilakukan untuk mendapatkan bakteri yang diharapkan mampu beradaptasi dan mendegradasi senyawa intermediate dari limbah minyak yang bertindak sebagai substrat awal. Untuk mendapatkan bakteri yang diharapkan tersebut dilakukan proses 
seleksi bakteri dengan cara menimbang sebanyak 5 gram sample tanah yang berasal dari bongkaran tanah tercemar minyak bumi yang telah diolah menggunakan teknik biofile; tanah disekitar lokasi Centralized Land Treatment Site (CLTS). Kemudian diinokulasikan ke dalam $100 \mathrm{ml}$ media biosurfaktan yang ditambahkan $1 \mathrm{~mL}$ minyak mentah, selanjutnya diinkubasikan pada shaker inkubator dalam suhu ruang selama 48 jam. Koloni bakteri yang tumbuh pada media biosurfaktan selanjutnya diinokulasikan pada media Nutrient Agar (NA). Inokulasi bakteri dilakukan sebanyak tiga kali untuk mendapatkan koloni dalam rentang waktu yang berbeda, yaitu 6 jam, 24 jam dan 48 jam. Koloni bakteri yang tumbuh selanjutnya dikultur pada media pengayaan, Nutrient Broth (NB), diinkubasikan pada suhu ruang pada shaker selama 24 - 48 jam.

\subsection{Identifikasi morfologi Isolat bakteri}

Identifikasi morfologi dilakukan dengan pewarnaan Gram. Kultur yang akan diuji digoreskan di atas kaca objek setelah dilarutkan dalam setetes akuades lalu dilewatkan di atas api. Isolat lalu diteteskan larutan crystal violet lalu dibilas dengan alkohol $70 \%$, lalu diteteskan larutan iodine dan kembali dibilas dengan alkohol70\%, terakhir diteteskan larutan safranin dan dibilas dengan menggunakan akuades steril lalu dikeringkan. Uji motilitas dilakukan dengan cara menginokulasi kultur dengan teknik stab ke dalam medium motilitas lalu diinkubasi selama 24-48 jam pada suhu ruang.(6)

Uji katalase dilakukan dengan cara meneteskan beberapa tetes $\mathrm{H} 2 \mathrm{O} 2$ 3\% diatas kaca objek lalu kultur diose dan diletakkan di dalam tetesan $\mathrm{H} 2 \mathrm{O} 2$. Uji oksidase dilakukan dengan cara meneteskan larutan $\square$-naftol $1 \%$ dan $0,3 \mathrm{ml}$ larutan p-aminodimetilalanin-oksalat ke dalam tabung medium NB yang sudah diinokulasi, lalu dikocok selama 5 menit. Uji sitrat dilakukan dengan menginokulasikan kultur ke dalam tabung berisi Koser Citrate Agar dan diinkubasi selama 48-72 jam. Uji Indol dilakukan dengan menginokulasi kultur ke dalam tabung berisi medium yang mengandung triptofan lalu diinkubasi selama 48 jam pada suhu $30-35$ 0C. Tambahkan $1 \mathrm{ml}$ larutan reagen Kovac atau Ehrlich ke dalam tabung, lalu dikocok dan letakkan dalam keadaan tegak. Uji gelatine dilakukan dengan menginokulasi kultur ke dalam medium gelatine, lalu diinkubasi selama 2472 jam pada suhu 300C, lalu dimasukkan lemari pendingin selama 10-15 menit. Fermentasi gula dilakukan dengan cara menginokulasikan kultur ke dalam medium cair yang mengandung gula (glukosa, laktosa, arabinosa, maltose) lalu diinkubasi pada suhu 35 0C selama 48 jam.(6)

\section{HASIL DAN PEMBAHASAN}

Seleksi, Isolasi dan identifikasi bakteri hidrokarbonoklastik merupakan salah satu dari rangkaian Kegiatan Optimasi Kinerja Bakteri Pendegeadasi Hidrokarbon pada Fase Substrat Transisi dalam Bioremediasi Tanah Terkontaminasi Minyak Bumi. Sebelum melakukan seleksi untuk memperoleh kultur yang mampu mendegradasi cemaran hidrokarbon, terlebih dahulu dilakukan sampling di berbagai lokasi yang diprediksi sebagai sumber bakteri pendegradasi hidrokarbon rantai lurus, aromatik maupun senyawa intermediate. Sampling dilakukan di lokasi lahan tercemar minyak yang berada di Bojonegoro dan Riau (Gambar 3.1).

\subsection{Seleksi dan Optimasi Bakteri pendegradasi cemaran hidrokarbon}

Dari berbagai isolat/konsorsium yang diperoleh dalam isolasi awal, selanjutnya dilakukan seleksi untuk menentukan konsorsium yang paling baik untuk proses degradasi minyak bumi dan senyawa intermediate yang terbentuk. Seleksi dilakukan dengan menggunakan 
media yang mampu menstimulus bakteri untuk menghasilkan biosurfaktan dengan menggunakan minyak sebagai sumber karbonnya. Selanjutnya dari media kultur tersebut dilakukan isolasi menggunakan media nutrient agar.

Hasil seleksi dan optimasi bakteri yang dilakukan pada berbagai sampel tanah yang berasal dari 28 tempat yang berbeda, diperoleh 4 konsorsium bakteri yang mampu mendegradasi senyawa hidrokarbon. Dengan kode konsorsium RISTEK 1222.3; RISTEK 122-5; RISTEK-122-BN5; dan RISTEK 122-Mix yang merupakan gabungan dari ketiga konsorsium tersebut.

\subsection{Identifikasi Morfologi bakteri}

Pewarnaan Gram merupakan pewarnaan diferensial yang digunakan untuk melihat apakah bakteri merupakan Gram positif atau Gram negatif. Pada bakteri setelah ditetesi larutan mordant (iodine) dan didecolorize menggunakan alkohol, kristal violet ikut terbilas. Penambahan counterstain (safranin) menyebabkan dinding sel terlihat berwana merah. Pada hasil pemeriksaan ditemukan 2 kultur merupakan Gram negatif dan 3 kultur merupakan Gram positif. Pada uji motilitas, ditemukan 2 kultur bersifat motil, sedangkan 3 kultur yang lain bersifat non motil.

Dalam uji katalase, diketahui semua kultur dapat menghasilkan enzim katalase yang dapat digunakan untuk mengoksidasi senyawa $\mathrm{H} 2 \mathrm{O} 2$ menjadi $\mathrm{H} 2 \mathrm{O}$ dan $\mathrm{O} 2$. Uji oksidase dilakukan untuk mengetahui keberadaan sitokrom oksidase. Jika terjadi perubahan warna pada medium menjadi warna biru atau keunguan maka kultur tersebut positif memiliki enzim sitokrom oksidase. Berdasarkan hasil uji, 2 kultur yang merupakan bakteri Gram negatif, positif memiliki sitokrom oksidase. Uji citrate

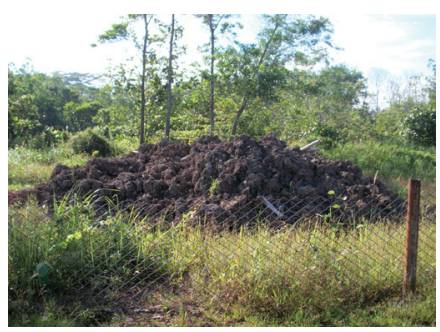

Bongkaran biopile

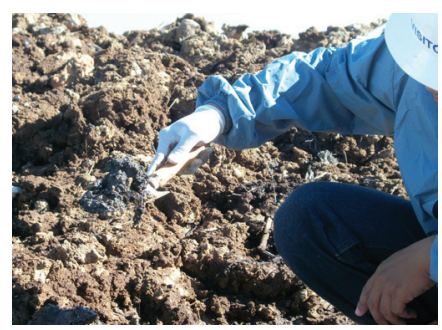

Centralized Land Treatment Site (CLTS)

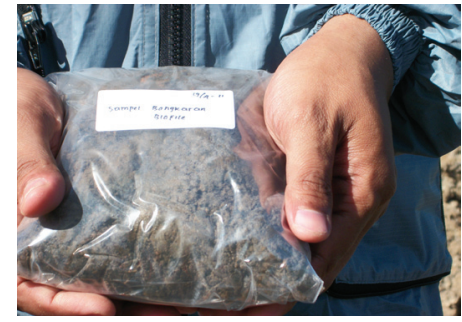

Sampel bongkaran biopile

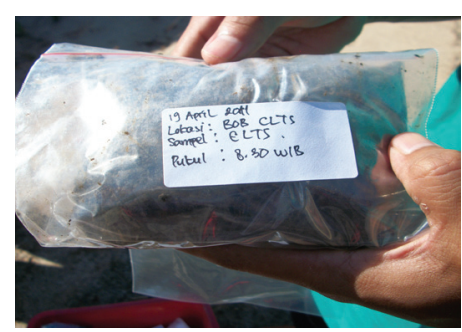

Sampel CLTS

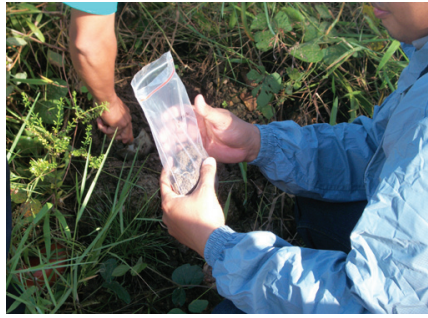

Lahan percobaan Fitoremediasi

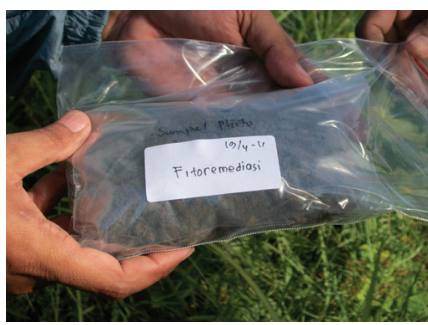

Sampel Fitoremediasi

Gambar 3.1 Sampling bakteri pendegradasi Hidrokarbon di Badan Operasi Bersama PT. Bumi Siak Pusako, Pertamina Hulu, Zamrud, Riau

Gram positif, dinding selnya dapat menyerap kristal violet dengan baik, sehingga sel berwarna ungu. Pada bakteri Gram negatif, dilakukan untuk mengetahui penggunaan sitrat sebagai sumber karbon. Jika medium berubah warna maka hal tersebut 
menunjukkan adanya pemanfaatan sitrat oleh sel. Berdasarkan hasil uji ditemukan bahwa hanya ada satu kultur yaitu Pseudomonas fluorescens yang dapat memanfaatkan sitrat sebagai sumber karbon. Uji indol dilakukan untuk mengetahui adanya enzim yang dapat mengubah triptofan menjadi indol. Degradasi triptofan menjadi kompleks indol ditandai dengan timbulnya perubahan warna pada lapisan atas medium menjadi merah tua.

Dari hasil uji yang dilakukan tidak ditemukan adanya kultur yang dapat merombak triptofan menjadi indol. Uji pencairan gelatin dilakukan untuk mengetahui adanya enzim gelatinase pada mikroba. Jika medium gelatin yang telah diinokulasikan kultur mencair pada suhu ruang, atau tidak bias kembali membeku saat diletakkan di dalam lemari pendingin maka kultur tersebut positif memiliki enzim gelatinase yang bersifat proteolitik. Karena gelatin merupakan sejenis protein, maka enzim gelatinase dapat memecah protein yang terdapat dalam gelatin. Berdasarkan uji yang dilakukan ditemukan 2 kultur bersifat positif dan 2 kultur bersifat negatif. Fermentasi gula dilakukan untuk mengetahui kemampuan bakteri pengujian yang dilakukan diketahui bahwa 3 kultur mampu memfermentasi glukosa sedangkan 1 kultur tidak bias. Kultur bakteri Gram negatif tidak bias memfermentasi maltose, dan laktosa, sedangkan arabinosa tidak dapat difermentasi oleh kultur bakteri Gram positif. Pada pengujian lainnya seperti urease, uji VP, dan hidrolisis pati dapat dilihat pada tabel 3.2-3.4 berikut.

Uji urease dilakukan untuk mengetahui ada tidaknya produksi ammonia pada medium yang mengandung urea. Keberadaan ammonia dapat diketahui dengan menggunakan $\mathrm{pH}$ alkali. Uji VP dilakukan untuk mengetahui kemampuan bakteri menghasilkan senyawa acetyl carbinol. Jika pada medium terjadi perubahan warna menjadi kemerahan, maka bakteri dapat meghasilkan senyawa acetyl carbinol. Pada hidrolisis pati, medium yang sudah diinokulasikan kultur, diteteskan larutan iodine untuk mengetahui pencernaan pati. Jika pada daerah sekitar koloni terdapat area bening maka bakteri positif memiliki enzim yang mampu mencerna pati.

Dari hasil identifikasi morfologi dan uji biokimia yang dilakukan di Laboratorium
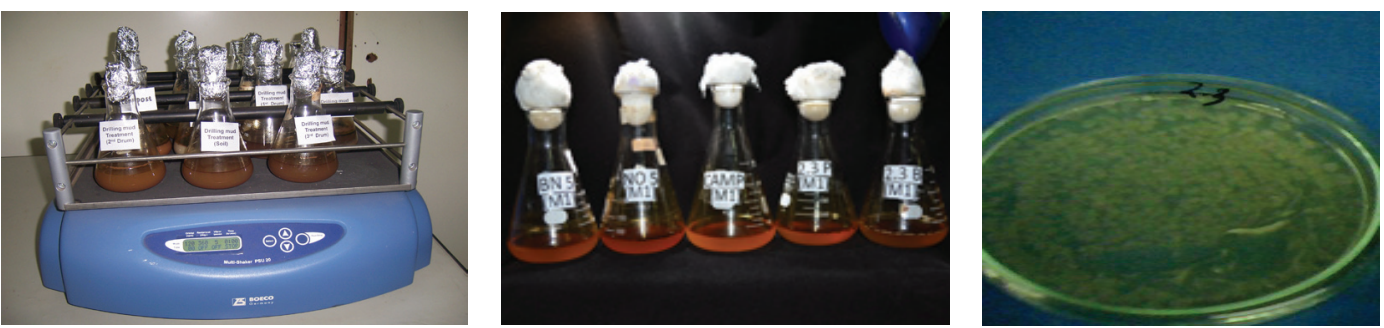

Gambar 3.2. Seleksi dan Optimasi Bakteri pendegradasi cemaran hidrokarbon

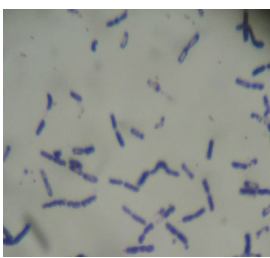

Ristek 122-2.3

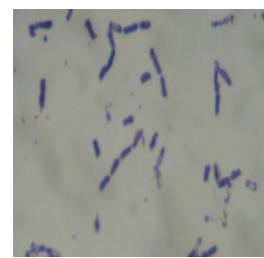

Ristek 122-BN5

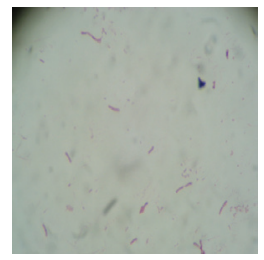

Ristek 122-5.1

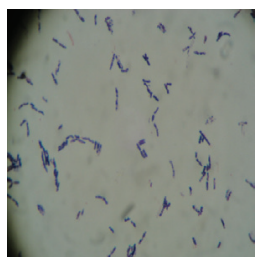

Ristek 122-5.2

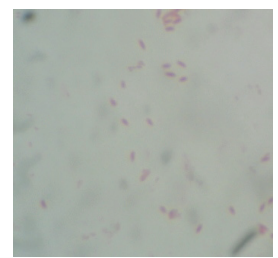

Ristek 122-5.2

Gambar 3.3 Identifikasi Morfologi bakteri

memfermentasi karbohidrat sederhana (glukosa, laktosa, maltose, arabinosa). Dari
Bakteriologi Institut Pertanian Bogor, isolat/ konsorsium bakteri hasil seleksi yang 
dilakukan di Balai teknologi Lingkungan, bakteri dengan kode Ristek 122-BN 5 dan 122-2.3 masing-masing merupakan isolat berdasarkan hasil identifikasi dan uji biokimia konsorsium bakteri tersebut terdiri dari Pseudomonas fluorescens, Bacillus insolitus

Tabel 3.1 Konsorsium bakteri pendegradasi hidrokarbon

\begin{tabular}{|c|c|c|c|}
\hline Kode Isolat/Konsorsium bakteri & Gambar & Koloni & Degradasi \\
\hline RISTEK 122-BN5 & & $\begin{array}{l}\text { - Bulat kuning } \\
\text { - Bulat putih } \\
\text { - Bulat putih bermata }\end{array}$ & +++ \\
\hline RISTEK 122-5 & & - Bulat putih & ++ \\
\hline RISTEK 122-2.3 & & - Bulat putih & +++ \\
\hline
\end{tabular}

Tabel. 3.2 Uji Biokimia isolat bakteri Ristek 122-5.1

\begin{tabular}{|c|c|c|c|c|c|c|}
\hline \multirow[b]{2}{*}{ No. } & \multirow[b]{2}{*}{ Kode bakteri } & \multicolumn{5}{|c|}{ Parameter uji dan Hasil reaksi : } \\
\hline & & Katalase & Oxidase & Pigment & $\begin{array}{l}\text { Pertumbuhan } \\
\text { pada } 420 \mathrm{CC}\end{array}$ & $\begin{array}{l}\text { Pertumbuhan pada } \\
\text { Mac Conkey }\end{array}$ \\
\hline \multirow[t]{7}{*}{2.} & \multirow[t]{7}{*}{ Ristek 122-5.1 } & Positif & Positif & Positif & Positif & Positif \\
\hline & & Maltose & Mannitol & Laktose & Xylose & Salicin \\
\hline & & Negatif & Positif & Negatif & Positif & Negatif \\
\hline & & Urease & Arginine & Ornitine & Citrate & Glukose \\
\hline & & $\begin{array}{l}\text { Dibius (bisa } \\
\text { positif atau } \\
\text { bisa negatif }\end{array}$ & Positif & Negatif & Positif & positif \\
\hline & & Gelatin & Casein & & & \\
\hline & & Positif & Positif & & & \\
\hline
\end{tabular}

tunggal; berdasarkan hasil identifikasi dan uji biokimia kedua isolat bakteri tersebut adalah Bacillus marinus. Bakteri dengan kode Ristek 122-5 merupakan konsorsium bakteri yang terdiri dari 3 isolat, dan Pseudomonas putida.

Pseudomonas sp merupakan bakteri hidrokarbonoklastik yang mampu mendegradasi berbagai jenis hidrokarbon. Bacillus insolitus mampu mendegradasi 
Tabel. 3.3 Uji Biokimia isolat bakteri Ristek 122-5.3

\begin{tabular}{|c|c|c|c|c|c|c|}
\hline \multirow[t]{2}{*}{ No. } & \multirow[t]{2}{*}{ Kode Isolat } & \multicolumn{5}{|c|}{ Parameter uji dan Hasil reaksi : } \\
\hline & & Katalase & Oxidase & Pigment & $\begin{array}{l}\text { Pertumbuhan } \\
\text { pada } 42 \text { OC }\end{array}$ & $\begin{array}{c}\text { Pertumbuhan pada } \\
\text { Mac Conkey }\end{array}$ \\
\hline \multirow[t]{7}{*}{1.} & \multirow[t]{7}{*}{ Ristek 122-5.3 } & Positif & Positif & Positif & Negatif & Positif \\
\hline & & Maltose & Mannitol & Laktose & Xylose & Salicin \\
\hline & & $\begin{array}{l}\text { Dibius (bisa } \\
\text { positif/ bisa } \\
\text { negatif) }\end{array}$ & $\begin{array}{l}\text { Dibius (bisa } \\
\text { positif/ bisa } \\
\text { negatif) }\end{array}$ & Negatif & Negatif & Negatif \\
\hline & & Urease & Arginine & Ornitine & Citrate & Glukose \\
\hline & & $\begin{array}{l}\text { Dibius (bisa } \\
\text { positif/ bisa } \\
\text { negatif) }\end{array}$ & Positif & Negatif & Negatif & positif \\
\hline & & Gelatin & Casein & & & \\
\hline & & negatif & Negatif & & & \\
\hline
\end{tabular}

Tabel 3.4 Uji Biokimia isolat bakteri Ristek 122-BN 5, Ristek 122-2.3 dan Ristek 122-5.2

\begin{tabular}{|c|c|c|c|}
\hline No. & Parameter uji & Hasil reaksi : & \\
\hline & & Ristek 122-BN 5, Ristek 122-2.3 & Ristek 122-5.2 \\
\hline 1. & Katalase & Positif & Positif \\
\hline 2. & Pertumbuhan pada media $\mathrm{NaCl} 7 \%$ & Dibius (bisa positif/ bisa negatif) & Negatif \\
\hline 3. & Pertumbuhan pada suhu $450 \mathrm{C}$ & Negatif & Negatif \\
\hline 4. & Citrate & Negatif & Negatif \\
\hline \multirow[t]{2}{*}{5.} & Pertumbuhan pada suhu An aerobik & Negatif & Negatif \\
\hline & Fermentasi gula: & 122-BN 5, Ristek 122-2.3 & Ristek 122-5.2 \\
\hline 6. & Glukosa & Positif & Negatif \\
\hline 7. & Arabinose & Negatif & Negatif \\
\hline 8. & Mannitol & Negatif & Negatif \\
\hline 9. & Xylose & Dibius (bisa positif/bisa negatif) & Negatif \\
\hline 10. & Gelatin hydrolisis & Positif & Negatif \\
\hline 11. & Casein hydrolisis & Dibius (bisa positif/bisa negatif) & Negatif \\
\hline 12. & Starch hydrolisis & Negatif & Negatif \\
\hline 13. & Indol & Negatif & Negatif \\
\hline 14. & Nitrate reduction & Dibius (bisa positif/bisa negatif) & Negatif \\
\hline 15. & VP test & Negatif & Negatif \\
\hline 16. & Urease & Negaitif & Negatif \\
\hline 17. & Nutrien Broth pH 6,8 & Negatif & Positif \\
\hline 18. & Nutrien Broth pH 5,7 & Dibius & Negatif \\
\hline
\end{tabular}

senyawa fenol terhalogenasi(4).

Pseudomonas putida merupakan salah satu bakteri yang mampu mendegradasi senyawa Poli Aromatic Hidrokarbon (PAH) mampu memanfaatkan naftalen, phenantren dan BTEX sebagai substrat(10). Pseudomonas fluorescens selain mampu mendegradasi Poli Aromatik Hidrokarbon (naftalen) juga mampu menghasilkan biosurfaktan viscosin dan lipopeptida. Lipopeptida biasanya terdiri dari 8 - 17 asam amino dan lipida (umumnya berupa hidroksi asam lemak) yang tersusun dari 8-9 gugus metilen(8),(10), dan

Biosurfaktan diekskresikan ke lingkungan dapat membantu melepaskan senyawa hidrokarbon dalam senyawa 
organik dan meningkatkan konsentrasi senyawa hidrokarbon dalam air melalui pelarutan ataupun emulsifikasi. Dengan teremulsikannya hidrokarbon maka akan meningkatkan kinerja bakteri dalam mendegradasi hidrokarbon dan berpotensi untuk digunakan dalam upaya bioremediasi lingkungan akibat pencemaran hidrokarbon.

\section{KESIMPULAN DAN SARAN}

\subsection{Kesimpulan}

Dari hasil identifikasi morfologi dan biokimia diketahui bahwa isolat/konsorsium bakteri hasil kegiatan seleksi dan isolasi bakteri pendegradasi senyawa hidrokarbon ini, terdiri dari Pseudomonas putida. Pseudomonas fluorescens, Bacillus insolitus dan Bacillus marinus, merupakan konsorsium bakteri yang berpotensi untuk dikembangkan dan diterapkan dalam bioremediasi lahan tercemar minyak bumi.

\subsection{Saran}

Formulasi bakteri yang tepat merupakan salah satu faktor penting dalam bioremediasi, Faktor lain yang perlu dikaji adalah mendapatkan formulasi media serta formulasi nutrisi yang tepat yang dibutuhkan pada proses bioremediasi di lapangan.

\section{Ucapan Terima Kasih}

Kegiatan ini dapat terlaksana dengan adanya Program Insentif Riset Peningkatan Kemampuan Peneliti dan Perekayasa (PKPP) Tahun 2011 serta peran aktif rekan-rekan satu tim. Terima kasih atas dukungannya.

\section{DAFTAR PUSTAKA}

1. Anonim, 2010, Faktor-faktor yang mempengaruhi pertumbuhan bakteri, http://syariffauzi.wordpress.com/tag/ faktor-faktor-yang-mempengaruhi- pertumbuhan-bakteri/. online: accessed 25 Mei 2010,

2. Black, J.G., 2002, Microbiology: principles and explorations, 5th ed., John Wiley \& Sons, xxiv $+762 \mathrm{hlm}$.

3. Budianto, H., 2008, Perbaikan lahan terkontaminasi minyak bumi secara bioremediasi, [URL: http://www.iec. co.id/bioremediasi1.html], online: accessed 18 October 2011

4. Wang, Chun Ching, Chi Mei Lee, Chih Hsien Kuan (2000), Removal of 2,4-dichlorophenol by Suspended and Immobilized Bacillus Insolitus, Chemosphere 41. P. 447-452, Pergamon.

5. Das, N. \& P. Chandran, 2011, Microbial degradation of petroleum hydrocarbon contaminats: an overview. Biotech. Res. Int. Vol. 2011. pp: 1-13

6. Gandjar, I., I.R.Koentjoro, W. Mangunwardoyo \& L. Soebagya, 1992, Pedoman Praktikum Mikrobiologi Dasar, Jurusan Biologi Fakultas Matematika dan Ilmu Pengetahuan Alam, Universitas Indonesia, vii + $87 \mathrm{hlm}$

7. KEPMEN LH 128 Tahun 2003. Keputusan Menteri Negara Lingkungan Hidup Nomor : 128 Tahun 2003, Tentang Tata Cara Dan Persyaratan Teknis Pengolahan Limbah Minyak Bumi Dan Tanah Terkontaminasi Oleh Minyak Bumi Secara Biologis.

8. Ruzniza, 2005, Production of Biosurfactant by Locally Isolated Bacteria from Petrochemical Waste, Thesis, Faculty of Science Universiti Teknologi Malaysia

9. Susilorukmi. A, Sriwuryandari. L, \& Sembiring. T., 2005, Aplikasi Mikroorganisme Untuk Bioremediasi Oil Spill Sistem Dua Tahap, Teknologi Indonesia 28: 29--37. LIPI PRESS.

10. Van Hamme, J.D., Ajay Singh and Owen P.W, 2003, Recent Advances in Petroleum Microbiology, Microbiology and Molecular Biology Reviews, p. 503549 . 